\title{
GCU
}

Glasgow Caledonian

University

University for the Common Good

\section{Disabled people as counterfeit citizens: the politics of resentment past and present} Hughes, Bill

Published in:

Disability and Society

DOI:

10.1080/09687599.2015.1066664

Publication date:

2015

Document Version

Author accepted manuscript

Link to publication in ResearchOnline

Citation for published version (Harvard):

Hughes, B 2015, 'Disabled people as counterfeit citizens: the politics of resentment past and present', Disability and Society, vol. 30, no. 7, pp. 991-1004. https://doi.org/10.1080/09687599.2015.1066664

\section{General rights}

Copyright and moral rights for the publications made accessible in the public portal are retained by the authors and/or other copyright owners and it is a condition of accessing publications that users recognise and abide by the legal requirements associated with these rights.

Take down policy

If you believe that this document breaches copyright please view our takedown policy at https://edshare.gcu.ac.uk/id/eprint/5179 for details of how to contact us. 
Disabled people as counterfeit citizens: the politics of resentment, past and present

\section{Bill Hughes}

Department of Social Sciences, Media and Journalism, Glasgow School for
Business and Society, Glasgow Caledonian University

Published in Disability \&Society (2015), 30 (7): 991-1004

\section{Introduction}

It has become clear in the last few years that disabled people are a core part of the much maligned 'underclass' that have come to constitute the fall guys for neoliberal state formation and the right wing, populist politics of resentment that has been mobilised against difference in the UK (Tyler 2013). Disabled people, of any UK minority community, have been 'the hardest hit' - by the cuts embodied in 'welfare reform'. Kaye, Jordan and Baker (2012) argue that disabled people are living on the edge of a social and economic precipice and that the human and financial cost of welfare cuts will do untold damage to the lives and prospects of millions of disabled people in the UK. Many feel that the tipping point has passed: The precipice is already claiming victims. By April 2013, the date for the implementation of all the proposed reforms, it was clear chronic poverty was inevitable for millions of disabled people. I argue, in this paper, that disabled people in the UK have been tipped into an abyss of counterfeit citizenship and smeared as 'false mendicants' - an old trick well documented in the historical archives of ableism. Neo-liberalism has employed this representation - widely used during the early modern period - as 'moral 
justification' for the pillory into which the entire disabled community has been placed. Austerity has found a scapegoat (O'Hara 2014: 173-208).

Transformed from deserving citizens into scroungers by right-wing 'workfare' discourse, the disabled identity has been tarnished (Scope 2011).Work Capability Assessment (WCA) constitutes a craven assault on dignity (O'Hara 2014: 190-198); positioning clients at the outset of the process as counterfeit claimants, who can only demonstrate their authenticity by passing what amounts to a lie detector test (HMSO 2011: 32-33) (1). The process is based on the suspicion of 'false mendicancy'; the outcome is, more often than not, a self-fulfilling prophesy. The experience of WCA, led an individual with mental health issues to conclude that: 'By default, it treats people as cheats' (Quoted in O'Hara 2014: 187). Administratively reclassified as non-disabled people, the WCA performs overnight cure; making 'folk devils' (Briant et al 2013) by tarnishing the majority of disabled people with the suspicion that has been reserved (historically) for the nefarious figure of the 'false mendicant'.

\section{From the politics of hospitality to the politics of resentment}

Emmanuel Kant argued that 'cosmopolitan hospitality' was an imperative for the realisation of 'perpetual peace' (1795/1991: 105-108). Jacques Derrida (2000: 128-9) argued that : 'Pure and unconditional hospitality, hospitality itself opens, or is in advance open, to someone who is neither expected nor invited, to whoever arrives as an absolute foreign visitor, as a new arrival, non-identifiable and unforeseeable, in short wholly other'. The post-WW2 social democratic consensus embodied, if not the universal ideals of hospitality expounded by Kant and Derrida, then, at least, it 
demonstrated intent to develop a system of social security - a safety net - to insure the protection and economic security of all citizens. The objective of the construction of a welfare state, dedicated to these ends begins to crumble in the 1970's with the rise of the 'new right' and the neoliberal critique of the 'nanny state'. In this critique the state welfare agenda is replaced by an accent on individual agency and selfreliance in which a discourse of benefits as 'hand-outs' and recipients as idle and feckless, supersedes the idea of public responsibility for the most disadvantaged people. Neo-liberalism proposes a doctrine of the survival of the fittest in a market unrestrained by collectivist forms of interference. The waste products of such a system are, from this perspective, a burden on those who can (are able to) cope and prosper. Bauman (2004) notes that in contemporary neoliberal societies, members of marginalized group have become homines sacri; persons classified as useless because they have been stripped of intrinsic value by the dominance of the market.The 'weak', - as neo-liberalism would have it - are best left to their own devises, since resources dedicated to their salvage will only exacerbate their dependency and constitute an economic break on worthy enterprise. The 'wounded' should be left behind to fend for themselves otherwise they will become a source of resentment.

The politics of resentment is a declaration of cultural insularity. According to Nietzsche (1967) 'ressentiment' is the attitude of hatred and denial that belongs to 'slave morality'. Resentment is the emotion associated with 'individuals, groups and national communities that have defined their identity in terms of feeling 'hard done by'; by the accusation' that an 'aggressor ... has transformed them into victims' (Fantini et al 2013: 4). This definition, one could argue, describes, according to the 
view of the Conservative party in the United Kingdom, , the suffering of the ordinary hard working people of Britain at the hands of a cunning, feckless underclass (Garthwaite 2012). Resentment has had many different meanings in history. It was used positively in the Scottish Enlightenment by Smith, Hume, and Lord Kames as a sentiment that could be appropriately mobilised as the underlying basis of sociability and progressive law making (Ferro 2010). In modernity, in right-wing circles, resentment has been associated with 'the powerless' particularly their envy of privilege and the explosions of anger that mark, riot, revolt or revolution. In this paper, I align resentment with contemporary neo-liberal populism and its identification of the oppressed, in general, and disabled people, in particular, with parasitism and suggest that it has precursors in the early modern period that shed light on its contemporary disposition.

Resentment embraces a 'blame culture' perfectly suited to the fabrication of scapegoats; the others deemed responsible for many of the problems, ills and evils of the world. In neoliberal Britain this is an intersectional scrum of disabled people, homeless people, Roma people, immigrants, asylum seekers and refugees, black and ethnic minority groups, so called 'chavs' and other people who live on the margins. 'They' - outsiders all - are depicted by the mass media as 'abject subjects' (Tyler 2013). The abjectified are relatively interchangeable in the repertoires of invalidation deployed by neo-liberalism and the finger of blame for structural inequalities is pointed at those persons in the community made most wretched by its hegemony (Mitchell 2014: 3). These repertoires consist of free floating, rhetorical frames of reference constructed by key agencies of representation as 'evidence' of the murky reputation of the oppressed. Pejorative depictions of idleness, 
dependency, fecklessness and fraudulent claims on the collective coffers are some of the charges shared by groups consigned to a position of counterfeit citizenship. Contemporary repertoires of invalidation are constituted by stigmatising signifiers; flexible markers of disrepute that are spliced into minority identities to the significant detriment of their social and ontological worth (Tyler 2013). In the neoliberal 'spaces and places' of policy exclusion and welfare retraction, disabled people lose their status amongst the cohorts of the deserving (Soldatic et al 2014) and become redefined in nefarious terms as 'shirkers and scroungers' (Garthwaite 2012)

In the neoliberal politics of resentment the 'majority' of 'hard working citizens' are mobilised to resent the so called parasitic classes who are depicted as enjoying privileges and favour which they do not deserve. The idea of the deserving poor is a non sequitur. It is being squeezed out of political discourse by a 'daddy state' (Wacquant 2012); a champion of individual agency that deplores, simultaneously, the economic and moral efficacy of 'hand-outs'. Any claim to desert - by the necessarily undeserving poor - is dismissed as a feckless demand by the degenerate 'underclass' that can only be saved from its self-appointed wretchedness by social insecurity. The undeserving are the 'workless' and they are opposed in neo-liberal populism to the 'hard working' moral majority (Goodley et al. 2014: 982). The creation of a polarised moral economy legitimates the class politics of income distribution, including the growing divide between rich and poor and the forced insecurity of the latter.

Forced insecurity is the means by which various strands of difference will be given the opportunity to 'better themselves'; pull themselves up by their own bootstraps 
(Grover and Soldatic 2013). The journey from resentment - its political popularisation by the leading political parties in the UK - to 'welfare reform' is a journey from the mediatised promotion of bitterness against the 'have-nots' to what Berlant (1997: 175) called 'hygienic governmentality'; the process of state minimization and its attendant resentful propaganda which claims that 'an abject population threatens the common good and must be rigorously governed and monitored by all sections of society'.

A discourse of 'inequality' is established, thereby - ironically by the political right - in which the ordinary working person, the taxpayer, the decent citizen; is the victim of injustice; treated unfairly relative to those who do not contribute - in economic and/or civic terms - to the community. For Max Scheler, the complex emotion of ressentiment is underpinned by a sense of injustice, including a sense of entitlement to what the other has (unjustly) procured: Ressentiment involves an 'illusory devaluation of the other man's qualities', including the falsifying of the values 'which could bestow excellence on any possible object of comparison' (Scheler 1961: 58). Those who procure resources without working are devalued in neo-liberal ideology; an ideology which mobilises repertoires of invalidation and stigmatisation that undermine the value of marginalised populations. This logic of resentment qua inequality is built into contemporary UK 'welfare reform' policy (DWP 2010a; 2010b) which claims that cutting benefits is the path to poverty reduction and a means of restoring the balance of fairness between the people who receive benefits and the people who pay for them' (2010a: 5). The abuse of the latter by the former underpins the legitimacy of a manifesto of redistribution from poor to better off. Social protection is redefined as 
[A] generous gift from 'us' to 'them' and transforms fairness from being about the rights of those in need to access material goods or employment, to a justification for strengthening that old principle of less eligibility. Social security as a source of social protection is marginalised with the result that the Coalition's discourse reinforces existing trends to turn social security into a mechanism for the transmission and achievement of ideological preferences for a smaller and more market oriented state, greater labour market flexibility and the portrayal of out of work benefits as morally corrosive (Wiggan 2012: 390).

It is not just the benefits that are 'morally corrosive' but the people who claim them. Hoggett et al (2013) argue convincingly that the UK Coalition government's reactionary anti-welfare populism blames disabled and sick people for consistent long term abuse of the benefits system. In this respect Incapacity Benefit claimants are the key target, depicted as malingerers concealing fitness to work in order to cheat ordinary, hard-working citizens out of their contribution to the commonweal. The co-location of disability and benefit fraud - effectively a discourse of criminalisation - has been a common theme in the media:

'There has been a significantly increased use of pejorative language to describe disabled people, including suggestions that life on incapacity benefit had become a 'Lifestyle Choice'. The use of terms such as 'scrounger', 'cheat' and 'skiver' was found in $18 \%$ of tabloid articles in $2010 / 11$ compared to $12 \%$ in $2004 / 5$. There were 54 occurrences of these words in 2004/5 compared to 142 in 2010/11. 
These changes reinforced the idea of disabled claimants as 'undeserving' (Strathclyde Centre for Disability Studies 2012: 5).

The vast sums of money taken from the pockets of disabled people in the past few years (Butler 2012) have been legitimated by this redistributive logic of resentment. The evidence suggests, that it is the poorest people in society that are affected, most significantly by benefit cuts (SPA 2011) and it is disabled people who are 'the hardest hit'. Demos (2013) calculated that 3.7 million disabled people in the UK are set to lose $£ 28.3$ billion by 2018 as a direct result of 'welfare reform'. This devastating cumulative outcome will be the result of government changes to eligibility with respect to six benefits. Ruth Levitas (2012) argues that neo-liberalism, under the Coalition government in the UK involved theft by the rich from the poor manifest, not only in massive benefit cuts for the poorest people in our communities but also in the 'Big Society', an idea designed to restructure civil society into a mixed economy of welfare. The 'mix' however, reduces public responsibility by emphasising private and third sector contributions: 'Talk of the 'Big Society' is, in the mouths of contemporary Conservatives, little more than an attempt to get necessary social labour done for nothing' (Levitas 2012: 322).

Redistribution in the interests of wealth and privilege - in this case removing state expenditure to allow the slack to be taken up the 'good citizens' of civil society - is one of the central challenges of neo-liberalism. After two centuries in which the doctrine of equality has flourished in one form or another, the neoliberal project seeks to render it inert. The politics of resentment provides a means to do so. By pitting the duties of citizenship - the first among which is hard work - against 
entitlement and rights (Owen and Parker Harris 2012) neoliberals ignite the flames of populism. In doing so, they mobilise pseudo-democratic sentiments of resentment against marginalised populations (Hogget et al 2013). The elaborate system for the protection of 'the weak', they argue, should be dismantled in order to protect the majority from the feckless 'under-class'.

Resentment and bitterness are the popular emotions that drive neoliberal politics (Hogget et al 2013). Aversive emotion - rather than reason - legitimates the negative social attitudes and the populist political affiliations that create and invalidate contemporary difference. Neo-liberal state formation relies increasingly on a politics of resentment in which a disgust response to difference and disability is mobilised (Hughes 2007; 2012a; 2012b).

Ableism, ethnocentrism, classism and racism are curried by sentiments of resentment. Resentment in contemporary neo-liberal Britain mobilises discrimination to abjectify marginalised groups (Tyler 2013). Disabled people, immigrants, the 'underclass' are portrayed as living the high life on the backs of working people and are accused of undermining an esteemed way of life. This is populism, an approach to politics that 'pits a virtuous and homogenous people against a set of ... dangerous 'others' who together are depicted as depriving (or attempting to deprive) the sovereign people of their rights, values, prosperity, identity and voice' (Albertazzi and McDonnell 2008: 8). Right wing populism in the UK is focused on the dangerous 'others' and mobilised (not against but) by the elite. It reinforces the values of neoliberalism, and protects both the dominance of the market and the interests of wealth and privilege. It has deepened in vociferousness, in the last few years, particularly in 
relation to the mobilisation of ethnocentrism, as the UK Conservative Party has fought to stave off the challenge of the United Kingdom Independence Party. The campaign for 'welfare reform', rooted in populist politics of moral invective, has moved disabled people into the ranks of the 'dangerous others' - part of that nefarious class of scroungers at whom the finger of resentment is pointedly directed (Briant et al 2013).

The politics of resentment forms an exclusionary emotional and social framework that traps minority identities and people experiencing multiple deprivations in its belief system and practices. Contemporary traps of resentment are constructed from 'reactionary or conservative revolutionary stances' based on the convictions of a 'declining petty bourgeois who are anxious to maintain order on all fronts' (Bourdieu 1984: 435). Tyler (2013:14) argues that: 'British citizenship has been redesigned to abjectify (my italics) specific groups and populations, producing paralysed, dejected and 'deportable' populations of non-citizens within the internal borders of the nation'. To abjectify is to invalidate the social worth of persons by de-humanisation. It is a stigmatizing practice that attaches moral negativity to people who are relatively powerless and alienated; depicting them as objects of disgust (Grover and Piggott 2013; Soldatic and Pini 2009; Soldatic and Meekosha 2012). With respect to the invalidation of disabled people, practices of abjectification have a long and chequered history; put to use in various contexts of state formation - ancient, medieval, modern and contemporary. In other words, in the historical pantheon, the application of a politics of resentment to disabled people is not a new phenomenon (Hunt 2003: 364). Ableism, throughout the ages, has embodied, in different forms, 
the mobilisation of a politics of resentment that constructs disability as a scapegoat. Below, I offer some examples as evidence of these invalidating processes.

\section{Disability and resentment: Scapegoat and 'sturdy beggar'}

The scapegoat is a social outlet for violence, a punching-bag for the mob. Those whose ontological validity is in question are the obvious candidates for the violence that brews in times of social crisis. Disability history is saturated with examples of ableism turning its machinery of violence on disabled people. The ambiguous moral status of disabled people in the Christian Middle Ages (Stiker 1999; Wheatley 2010) vindicates both giving and maltreatment simultaneously. Disabled people walk a tightrope between a position in which they are objects of charitable intention and a theological discourse that reduces impairment to wicked sinfulness. Non-disabled responses to disability were, therefore, prone to fickleness. Below I will examine two forms of resentment against disabled people that evolved during the early modern period. The first, draws attention to the way in which disability is drawn into association with the greatest folk devil of the early modern period; the figure of the witch and to the wider context of 'persecution' in which the reputation of disabled people is undermined and invalidated by the connection to the most perfidious behaviours of the age (Quarmby 2011).

Secondly, I examine how resentment against disability has arisen as a response to the role of begging and its place in the moral economy. 'False mendicancy' tests the tolerance of communities and the uncovering of a 'sturdy beggar' tends to sharpen suspicion that disabled people suffer more from idleness than impairment. The 'sturdy beggar' transformed into a scapegoat or a folk devil is not good news for 
disabled people. I focus on the early modern period but extend the analysis briefly into modernity. In so doing, I wish to indicate some element of historical continuity between the contemporary situation in which disabled people are being portrayed as counterfeit citizens and a past in which the shadow of suspicion has been thrown on disabled people by the notorious figure of the sturdy beggar.

In the profoundly bloody and socially disruptive period of early modern European history which included the renaissance and the reformation, state formation was marked by what Moore (1987) describes as a 'persecuting society'. Resentment took the form of violent suppression of heresy or 'holy violence' (Gaddis 2008)and included the torture and elimination of disabled people, particularly women of difference, who were caught in the conflagrations associated with the Witch Hunts (Quarmby 2011): Moore argues (1987: 5): 'Socially sanctioned violence began to be directed through established governmental, judicial and social institutions against groups of people defined by general characteristics such as race, religion, or way of life and that membership of such groups in itself came to be regarded as justifying the attacks'.

The witch was regarded as an abominable agent of Satan; a foul temptress in the service of the devil (Karlson 1998). Folk healers, wise women, midwives and 'crones' were targets for the witch hunters. The cocktail of femininity, old age and disability were the key signifiers, the most palpable signs of demonic possession. Accused 
women were tainted with bodily marks of abjection: 'commonly old, lame, bleareyed, pale, foul, full of wrinkles ... lean and deformed showing melancholy in their faces (Quoted in Quarmby 2011: 30). Not only was the witch a disabled, gendered figure, she was also regarded as a cause of impairment and disease. A well-known witch hunter declared that witches; 'afflict people with all kinds of ills of the stomach and the head and the feet, with colic, paralysis, apoplexy, leprosy, epilepsy, dropsy, strangury, etc. And they do so easily with the help of Satan' (Andreski 1989: 92). The hunt for witches mapped out the moral landscape, 'clarified' right and wrong, good and evil and provided a visceral apparatus for social control for those branded as threats to state, church and society: Witch-hunting was central to the exercise of power and to the formation of sovereignty: It constituted women and disabled people as inferior, filled the coffers of the churches, helped to prosecute heresy and dissent, reinforced the power of monarchs and the sway of religion - protestant and catholic hierarchies alike - identified scapegoats for misfortune and disaster. The vicious suppression of disabled people was a key weapon in the battle against Satan. The reputation of disability in the early modern period also came under attack from the economic and social conditions that began to break the bonds of feudal social relationships, creating displaced populations of itinerants and beggars (Bieir 1985)

The idea that disability is a byword for cunning deception has a long history, with Richard 111 the most prominent figure in this tradition (Mitchell and Snyder 2000: 95-118) . Questions over the moral worth and trustworthiness of disabled people are evident in a number of different contexts. In ancient Rome, the 'false mendicant', 
exposed as a charlatan was the target of mob violence. Some were stoned to death (Garland 2010: 25-26). They became objects of resentment in times of social and economic crisis. In the middle-ages, 'the fear of beggars feigning disabilities resulted in a number of laws limiting their movements to specified areas, the places in which they were born or areas in which they were licensed' (Wheatley 2010: 22). The idea of the 'sturdy beggar' was embodied in English law in the Fourteenth century as a means of identifying and criminalizing the nefarious practices of mendicants and vagrants who feigned incapacity for monetary gain (Jutte 2013). The 'sturdy beggar' or 'false mendicant', as a usurper of the sacred system of charity, became a legendary figure in the middle-ages. The 'sturdy beggar' corrupted the munificence of the squire; turned the generous gift of the nobleman into an empty gesture; squandered the good will of bishop or priest; converted decency, propriety and piety into empty gestures. There was no one more scurrilous in the whole of Christendom than those who feloniously misappropriated the generosity of the privileged. . The 'sturdy beggar' - falsely or justly accused (and the former was common amongst partially sighted mendicants (Wheatley 2010)) cast a long shadow of suspicion over every disabled person, not just those who were forced by necessity to go 'cap in hand'. Worst of all, perhaps, the vagrant or wandering mendicant was, in effect, a man without a master; most offensive, by the very nature of this freedom, in a feudal context where everyone was supposed to have and to know their place in the social hierarchy.

In the early modern period, in order to prevent wilful malingering and stifle the geographical mobility of wandering vagrants, vagabonds and rogues, the 'sturdy beggar' was outlawed across Europe. Punishment - at which state functionaries in 
Tudor England excelled - included the pillory, the ducking stool, incarceration in local 'Bridewells', expulsion from the locality, branding and ear-boring. The last two examples of justice marked the body with an indelible criminal record (Jutte 2013). 'Sturdiness' was a matter of interpretation much as Work Capability Assessment is today. The criminalization of the 'sturdy beggar' in medieval and early modern Europe, however, drew a veil of suspicion over the legitimate mendicancy of the 'impotent poor' (or those with 'authentic' impairment - again a matter of interpretation) and exacerbated wariness and resentment of disabled people who were forced to survive in the same social space as their rogue counterparts (Jute 1981).

The 1601 act for the Relief of the Poor in Britain was a piece of pivotal welfare legislation that stayed on the statute books until 1834: The parish took responsibility for the welfare of paupers in its jurisdiction and controlled the distinction between the deserving and the undeserving poor. Disability kept the 'deserving' status that it had acquired during the Christian Middle Ages but 'counterfeit disability', embodied by the notorious figure of the sturdy beggar fell into the latter category. This rogue figure came under the jurisdiction of the vagrancy laws where it joined the growing legions of moral contempt: the idle, the itinerant, the alien including gypsies, the Irish, 'blackamoores' (Mayall 1997) and the homeless (Woodbridge 2001: 22-3) as well as prostitutes and harlots. Disability was forced into a position of moral ambiguity until evidence of authenticity - at an individual level - was established. 'Counterfeit disability' in the wake of 1601 act was branded or whipped and became a central feature of the portrait of the criminal stereotype in the $16^{\text {th }}$ and $17^{\text {th }}$ centuries (Beier 
1985). Most importantly, the boundaries between disability as an authentic or counterfeit status became blurred.

Thomas Harman's A Caveat for Common Cursitors - an enormously popular work describing early modern vagrancy and the lives of false beggars and vagabonds in England which was published in 1566. Woodbridge (2003) warns against its historical authenticity. It is the work of a privileged man with a venomous view of 'the poor' and a penchant for pop-sociology. Woodbridge attacks Harman's mythology and the historians that have swallowed it. Harman's work is the high point of a significant early modern genre of 'rogue' literature filled with tales of underworld figures and fake disabilities:

'dummerers who feign dumbness as an aid to soliciting alms counterfeit cranks who feign epilepsy and jarkmen who forge begging licenses. But this professionalized system of criminal specializations stands in stark contrast to the improvisational, hand-to-mouth subsistence of real vagrants as established by nearly all modern historians of vagrancy.... Harman and his fellow writers of "rogue literature" insist that vagrants are jobless by choice, out of sheer idleness' (Woodbridge 2003: 203)

Woodbridge argues that there is scant evidence for the existence of a 'rogues' lexicon or 'cant'. She advises historians to dismiss the academic value of modern 'rogue' literature. It should be read like Tudor 'Jest Books' - a form of fiction; a 
comedy genre that cannot be taken seriously as a work of 'social history' or criminal typology. However, 'rouge literature' was a powerful source of representation that informed opinion amongst the privileged classes. The growing ranks of the poor, including people with impairments, displaced by the transition of feudalism to capitalism, by the enclosures and by massive demographic expansion became a source of fear anxiety and moral panic. The rogue, the vagabond and the beggar were represented as idle, criminal reprobates; 'systematically marginalized and demonized through official discourse' (Carroll 1996: 15). The term rogue becomes a legal term for 'sturdy beggars' and other poor vagrants in the Poor Law legislation of 1572. 'Rogue' literature together with official discourse shapes the representation of the displaced poor and disabled people as a 'monstrous class' of drifters and malingerers (Skeggs 2014).

There is a strong movement towards de-sanctification of mendicancy in the early modern period. Its aura of holiness is gradually undermined. Martin Luther, in his popular manuscript Liber Vagatorum (1528), offered a savage indictment not only of 'sturdy beggars' but of the mendicant way of life. In this theological contribution to rogue literature Luther demonises the mendicant. In rolling back the Franciscan, medieval notion of the 'holy beggar', the great theologian situates begging as a nefarious tool in the immoral lives of rogues and tricksters. He reproduces repertoires of invalidation that sustain the view of the disabled poor as parasitical monsters. Work, not charity, is the proper, (protestant) way to sustain God's grace. 'A new set of values' derived from reformation and renaissance humanism celebrates the virtue 'of worldly activity and success' (Beier 1985: 4). Disability is 
placed in an ambiguous situation in the moral economy; with a question mark over its deserving status.

As modernity evolved, the beggar continued to be a figure that haunted disabled people; raising suspicion about their integrity. The enlightenment focus on dependency as a scourge of the emerging market economy placed the beggar in an uncomfortable space within a fragile moral economy. Modernity struggled with the development of a public philosophy and system of charity that could deal with the great displacements and damage - physical and mental - that marked industrialisation and the rise of capitalist social relations. 'Physiognomic practices' argue Snyder and Mitchell (2006: 41) became a staple of the new 'science of alms' and played a key role in an era that judged citizens' worth on the basis of their possession of a full range of normative bodily, sensory and cognitive capacities'. In early to mid-nineteenth century America, beggars were loathed and became 'synonymous with social irresponsibility and willed incapacity, as their presumed unsuitability for labour' was interpreted as 'choice rather than a socially conditioned fate' (ibid: 40). The counterfeit nature of disability was presumed on this basis. Yet, as in the past, the 'sturdy beggar' was an empirical rarity and the numbers of disabled people who begged constituted a relatively small proportion of the disabled population. The data were, however, a poor substitute for myth and the numbers of counterfeit mendicant no protection against the excesses of ableism.

Doubts about the authenticity of beggars merge - in modern welfare systems - with doubts about the authenticity of claims for compensation and support as if the latter is the equivalent to the former but with the state replaced by the private citizen as the 
dupe, or victim of feloniously misappropriated resources. For example, injured First World War veterans in the USA were widely accused of exaggerating their infirmities by doctors assessing them for compensation (Hickel 2001). Richard Scotch (2001: 376 ) argues that US Disability policy in the $20^{\text {th }}$ century chimes consistently with questions of desert: 'In every type of disability policy and program, from veterans pensions to vocational rehabilitation, from insurance to civil rights, notions of moral worth and social worthiness have played a central role in determining what individuals have qualified for benefits or protections'. These assessments and their concomitant moral suspicions are manifest in the abjectification and vilification of beggars in nineteenth and twentieth century urban America. City statutes collectively and commonly known as the 'Ugly Laws - designed to sweep both mendicancy and disability from the streets, were legal markers of bourgeois intolerance of the (visible) fragility of the American dream (Schwiek 2009). Normate, Bourgeois culture was sickened equally by the 'sturdy beggar' and the unsightly 'mutilations' of those who were most evidently not (ibid: 38). The counterfeit and the real merge into a singular figure in which the counterfeit dominates. This, I suggest, has become the case in contemporary neo-liberal Britain.

\section{Conclusion}

How do the contemporary politics of resentment work? A bushfire requires a single spark. The ignition of disability as a neoliberal scapegoat or 'folk devil' (Briant, Watson and Philo 2013) rekindles the historical flames of ableism by reproducing, in modern form, the discourse of 'false mendicancy' and the affect structure of resentment that underpins it. The idea that social assistance and state welfare are 
euphemisms for dependency and the lifestyle choice of the malingering classes provides the neo-liberal apparatus with the justification to air the suspicion that implicates disabled people in benefit fraud. Populist resentment makes the leap from suspicion to accusation a relatively short one.

In the making of the scapegoat or the folk devil, evidence has a limited place. It matters not a lot how many disabled people are caught with their hands in the welfare till, or, more accurately, interpreted, by 'Work Capability Assessment' as being 'on the take'. One or two or a few will suffice! The relationship between sample and population, that central guide in the gathering of reliable evidence, is largely superfluous. The evidence suggests that just over $1 \%$ of disability benefit claims are false but that the public take the view that the figure is nearer to $30-40 \%$ (Baumberg 2012). Likewise, the 'rogue' fictions of early modern England transformed the itinerant poor and disabled people into a criminal underworld of vagabonds and false mendicants; a vision little associated with reality that found a place at the heart of the social policy response of the day. The scapegoat is constructed by (social) extrapolation from one or two cases- real or fictitious- to the many; from the assignation of negativity and nefarious conduct in the case of one or a few individuals, to the inclusion of everyone in the group in a homogeneous class of social degenerates (Girard 1986). The taint travels quickly, like the metaphorical bushfire. The sturdy beggar became the mythical troublesome figure of crisis torn early modern England, until transportation to the Colonies solved the problem of entropic labour in the first few decades of the $17^{\text {th }}$ century (Tawney 1967). 
In the contemporary context, 'others' - those who share life on the margins with disabled people, through unemployment, underemployment and poverty - have also been drawn into the flames and abjectified by anti-welfare populism (Tyler 2013). The creation of precariousness goes hand in hand with the accusation of counterfeit citizenship. The neo-liberal state builds its legitimacy by constructing a phantom of 'reactionary intersectionality'; a vision of an 'underclass' of parasitic undesirables who live off the hard working moral majority. A great many of these persons who are constructed as the parasite class are claimants of disability benefits. By this means of myth making the 'scapegoat' is constructed as a heavy fiscal burden and is a category populated by massed ranks of pseudo-criminalized undesirables. Disabled people are not alone. They are not the only 'false mendicants' making claims on the neoliberal state. The politics of resentment has armies of undesirables to choose from.

What does matter, in the making of the scapegoat (in the form of the counterfeit citizen) is the spread of the discourse of suspicion and accusation and whether or not its proponents have the power to fan the flames of moral outrage. State and media, in unison, are well placed to stoke the fires and, in relation to disabled people, have done so with the skill of practiced arsonists. Even the Commons Select Committee on Work and Pensions in the UK offers testimony to this effect (HMSO 2012: 34-36). The 'false mendicant' - practicing peculation at every opportunity against state and fellow citizen - is alive and well in contemporary neoliberal discourse. People with invisible or fluctuating impairments and with mental health difficulties are very likely to be re-categorised as fit for work in the wake of assessment and while the taint of fraudulent behaviour is less likely to apply in these 
circumstances; a trace of suspicion may remain (2). Benefit fraud is an accusation implicit in neoliberal assumptions about welfare. Welfare-to-work programmes in the heartlands of neo-liberalism, have been founded on the suspicion - though not unusually on the explicit claim - that the 'underclass', mired in dependency, have taken to unemployment as a lifestyle choice; a choice made easy by a 'nanny state' prone to spoiling its offspring (Wiggan 2012) . Doubts raised about the authenticity of Incapacity Benefits claims by New Labour in the UK, shifted the discourse of welfare desert to the extent that disabled people were transported as an abstract category into the ranks of the undeserving, parasite class. It is becoming ever more apparent, as Scope (2011) indicated in a recent document that the growth of hate crime against disabled people in the UK has been fostered by the resentment of the moralized and moralizing majority that has come to accept the authenticity of the neo-liberal myth that disabled people are idle scroungers (Hoggett et al 2013). Work Capability Assessment (WCA) reproduces and broadens the accusation of fraudulent claiming. Even countless successful appeals against its outcomes cannot dispel the myth of counterfeit citizenship. WCA recategorees are cheats by definition. The redrawing of the criteria that transform - with immediate effect - incapacity into capacity widens - once again - the scope of those who are charged, at least symbolically, with felonious misappropriation. In medieval France exposed 'false mendicants' had their eyes put out (Wheatley 2010). In early modern England, it was the pillory, the whip or the stocks; though branding was not uncommon: Plus ca change!

\section{Notes}

(1) I make this claim on the basis of evidence submitted to the Work and Pensions Commons Select Committee (HMSO 2011: 32-33) by disabled 
people who had experienced the WCA process: their stories suggested that they relate to the process in terms of 'passing' and 'failing' where to fail is be declared 'fit for work'. The concept of 'failure' is, therefore, interpreted as a vindication of the authenticity of the life lived prior to the assessment. To pass suggests that one has lived a lie and has been uncovered as a scrounger. Interestingly, in a back-handed way, Professor O'Donnell of ATOS Healthcare lends support to clients perceptions that accusations and indignities are built into the system of assessment: 'One thing that would make a difference', he argues, 'would be if we could find a way of explaining to people that failure to be awarded ESA (Employment and Support Allowance) is not the same as being classed as a malingerer ... I think we need to get that across very clearly' (HMSO 2011: 29).

(2) Thanks go to an anonymous reviewer for pointing out this distinction References

Albertazzi, D. and McDonnell, D. 2008. Twenty-first century populism: The spectre of western European democracy. Basingstoke: Palgrave.

Andreski, S. 1989. Syphilis, Puritanism and witch hunts. New York: St. Martin's Press.

Baumberg, B. 2012. Perceived fraud in the benefits system, Inequalities, http://inequalitiesblog.wordpress.com/2012/06/12/perceived-fraud-in-the-benefitssystem/ 
Bauman, Z. 2004. Wasted lives: Modernity and its outcasts. Cambridge: Polity Press.

Berlant, L. 1997. The queen of America goes to Washington: Essays on sex and citizenship. Durham, NC: Duke University Press.

Beier, A.L. (1985) Masterless Men: The Vagrancy Problem in England 1560-1640, London; Routledge

Bourdieu, P. (1984) Distinction: A Social Critique of the Judgement of Taste, London: Routledge

Briant, E. Watson, N. and Philo, G. (2013) Reporting disability in the age of austerity: the changing face of media representation of disability and disabled people in the United Kingdom and the creation of 'folk Devils, Disability \& Society, 28 (6): 874-889

Butler, P .2012. Disabled people hit especially hard by cuts, finds report, Guardian, June 22, 2012: Retrieved from

http://www.guardian.co.uk/society/2012/jun/22/disabled-people-hit-hard-cuts

Carroll, W. 1996. Fat King, Lean Beggar: Representations of Poverty in the Age of Shakespeare, New York: Ithica

Demos .2013. Disabled people set to lose £28.3 billion of support, http://www.demos.co.uk/press release/destinationunknownaplil2013 (Accessed 17.1.14) 
Derrida, J. 2000. Of hospitality. Stanford: Stanford University Press.

Department for Work and Pensions. 2010a. $21^{\text {st }}$ century welfare. The Stationary Office Limited www.dwp.gov.uk/21st-century-welfare (Accessed 11/1/2014)

Department for Work and Pensions. 2010b. Universal credit: Welfare that works. The Stationary Office Limited www.dwp.gov.uk/universal-credit (Accessed 11/1/2014)

Fantini, B., Murono, D., and Moscoso, J. (Eds.). 2013. On resentment: Past and present. Newcastle-Upon-Tyne: Cambridge Scholars Press.

Ferro, M. 2001. Resentment in history, Cambridge: Polity Press

Gaddis, M. 2005. There is no Crime for those who have Christ, Berkeley and Los Angeles: University of California Press

Garland, R. 2010. The eye of the beholder: Deformity and disability in the GraecoRoman world, London: Bristol Classical Press

Garthwaite, K. 2012. The language of shirkers and scroungers? Talking about illness, Disability \& Society, 26 (3): : 369-372

Girard, R. 1986. The scapegoat, John Hopkins University Press: BaltimoreGrover, C. and Piggott, L. (2013) Disability and social insecurity; emotions, contradictions of 
'inclusion' and employment support allowance, Social Policy and Society, 12 (3): $360-380$

Goodley, D., Lawthom. R., Runswick-Cole, K. 2014. Dis/ability and austerity: beyond work and slow death, Disability \& Society, 29 (6): 980-984

Grover, C., and Soldatic, K. 2013. Neoliberal restructuring, disabled people and (in)security in Australia and Britain, Scandinavian Journal of Disability research, 15 (3): $216-236$

Hickel, W. 2001. Medicine, bureaucracy and social Welfare: The politics of disability compensation for American veterans of World War 1. Eds. P. Longmore and L. Umanski, 236-267. New York: New York University Press

HMSO .2011. The role of incapacity benefit reassessment in helping claimants into employment http://www.publications.parliament.uk/pa/cm201012/cmselect/cmworpen/1015/10150 $\underline{4 . h t m}$

Hoggett, P., Wilkinson, H. and Beedell, P. 2013. Fairness and the politics of resentment. Journal of Social Policy 42, (3): 567-85

Hughes, B. 2007. Being disabled: Towards a critical social ontology for disability studies. Disability \& Society 22, (7): 673-684. 
Hughes, B. 2012a. Fear, pity and disgust: Emotions and the non-disabled imaginary. In Handbook of Disability Studies, eds. N. Watson, A. Roulstone and C. Thomas, 6778 London: Routledge.

Hughes, B. 2012b. Civilising modernity and the ontological invalidation of disabled people. In Social Theories of Disability: New Developments, eds. D. Goodley, B. Hughes and L. Davis 17-32. Basingstoke, Palgrave.

Hunt, A. 2003. From moral science to morar regulation: Social theory's encounter with the moral domain, pp. 364-383, in G. Delanty and F. Isin (Eds.) Handbook of Historical Sociology, London: Sage

Jutte, R. 1981. Poor relief and social discipline in sixteenth-century Europe, European History Quarterly, 11 (1): 25-52

Jutte, R. 2013. Vagrants and beggars. Gale Encyclopaedia of the Early Modern World, http://answers.com/topic/vagrants-and-beggars (Accessed 1.27.14)

Kant, E. 1795/1991. Perpetual peace: A philosophical sketch. In Kant: Political Writings, ed. H. Reiss 93-130. Cambridge: Cambridge University Press.

Karlson, C. (1998) The Devil in the Shape of a Woman: Witchcraft in Colonian New England, New York: W. Norton and Company Kaye, A., Jordan, H., and Baker, M. 2012. The tipping point. http://thehardesthit.files.wordpress.com/2012/10/the tipping point oct.2012.pdf (Accessed 12/12/2013) 
Levitas, R. 2012. The just's umbrella: Austerity and the big society in coalition policy and beyond, Critical Social Policy, 32, (3): 320-342

Mayall, D. (1997) Egyptians and Vagabonds: Representations of the Gypsy in Early Modern Official and Rogue Literature', Immigrants and Minorities, 16 (3): 5582Mitchell, D. 2014. Gay pasts and disability future(s) tense. Heteronormative trauma and the parasitism of Midnight Cowboy, Journal of Literary and Cultural Disability Studies, 8 (1): 1-16

Mitchell, D., and Snyder, S. 2000. Narrative Prosthesis: Disability and the Dependencies of Discourse, Ann Abbor: University of Michigan Press

Moore, R. 1987. The formation of a persecuting society. Oxford: Basil Blackwell.

Nietzsche, F. 1967. On the genealogy of morals and ecce homo. Translated by W Kaufman: New York: Vintage Books.

O'Hara, M. 2014. Austerity Bites, Bristol: Policy Press

Owen, R., and Parker Harris, S. 2012. No rights without responsibilities: Disability rights and neoliberal reform under New Labour, Disability Studies Quarterly, 32 (3) http://dsq-sds.org/article/view/3992/3800 
Quarmby, K. 2011. Scapegoat: Why we are failing disabled people. London: Portobello Books.

Scheler, M. 1961. Ressentiment. Edited by L. Coser: Translated by W. Holdheim: New York: Schoken Book.

Schweik, S. 2009. The ugly laws. New York: New York University Press.

Scope. 2011. Deteriorating attitudes towards disabled people.

www.scope.org.uk/news/attitudes-towards-disabled-people-survey (accessed 16.1.2014)

Scotch, R. 2001. American disability policy in the twentieth century. In The new disability history. Eds. P. Longmore and L. Umanski, 375-392. New York: New York University Press.

Skeggs, B. (2014) Legitimating slow death: A Brief but long history of the use, abuse and demonization of labour by the media (Online) Available at https://values.doc.gold.ac.uk/blog17/ (accessed 2 Oct 2014)

Snyder, S., and Mitchell, D. 2006. Cultural locations of disability. Chicago and London: The University of Chicago Press.

Soldatic, K., and Meekosha (2012) The place of disgust: Disability, class and gender in spaces of workfare, Societies, 2 (4): 139-56 
Soldatic, K., and Pini, B. (2009) The three D's of welfare: Disability, disgust and deservingness, Australian Journal of Human Rights, 15 (1): 77-96

Soldatic, K. Roulstone, A. and Morgan, H. (Eds.) 2014. Disability, Spaces and Places of Policy Exclusion', London: Routledge

SPA .2011. In defence of welfare: The impact of the spending review. Social Policy Association: London www.social-policy.org.uk/downloads/idow.pdf (Accessed 13.1.2014)

Stiker, H.J. 1999. A history of disability. Translated by W. Sayers, Ann Arbor: University of Michigan Press.

Strathclyde Centre for Disability Studies. 2012. Bad news for disabled people: How the newspapers are reporting disability, University of Glasgow and Inclusion London: London.

Tawney, R. H. (1967) The Agrarian Problem in the Sixteenth Century, New York: Harper and Row

Tyler, I. 2013. Revolting subjects. London: Zed Books.

Wacquant, L. 2010. Crafting the neoliberal state: Workfare, prisonfare and social insecurity. Sociological Forum, 25, (2): 197-220. 
Wheatley, E. 2010. Stumbling blocks before the blind: Medieval Constructions of a

Disability. Ann Arbor, University of Michigan Press.

Wiggan, J. 2012. Telling Stories of $21^{\text {st }}$ Century Welfare: The UK coalition government and the neo-liberal discourse of worklessness and dependency, Critical Social Policy, 32, (3): 383-405.

Woodbridge, L. 2003. Jest Books, the Literature of Roguery, and the Vagrant Poor in Renaissance England', English Literary Renaissance, 33: 201-210

Woodbridge, L. 2001. Vagrancy, Homelessness, and English Renaissance Literature, New York: Urbana, 2001 